\title{
Paideusis
}

\section{John Dewey: Closet Conservative?}

\section{David I. Waddington}

Volume 17, Number 2, 2008

URI: https://id.erudit.org/iderudit/1072430ar

DOI: https://doi.org/10.7202/1072430ar

See table of contents

Publisher(s)

Canadian Philosophy of Education Society

ISSN

0838-4517 (print)

1916-0348 (digital)

Explore this journal

Cite this article

Waddington, D. (2008). John Dewey: Closet Conservative? Paideusis, 17(2), 51-63. https://doi.org/10.7202/1072430ar

\section{Article abstract}

Several well-known scholars, including Clarence Karier, Walter Feinberg, and Eamonn Callan, have offered arguments suggesting that John Dewey was more politically conservative than is generally thought. Karier and Feinberg base their respective cases on Dewey's involvement with Polish community during World War I, while Callan relies heavily on some remarks offered in one of Dewey's later works, Ethics. In the following account, it is suggested that neither of these analyses withstands careful scrutiny. In the case of the Polish affair, Karier and Feinberg are not able to marshal sufficient evidence to condemn Dewey convincingly, and there is a significant quantity of counterevidence which indicates that Dewey's intentions were benign. Callan's case, though seemingly convincing, is undermined by the joint authorship of the Ethics and by information contained in Dewey's correspondence. In conclusion, it is argued that the more popular understanding of Dewey as a left-liberal reformer is, in fact, correct. (c) David I. Waddington, 2008

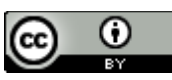

This document is protected by copyright law. Use of the services of Érudit (including reproduction) is subject to its terms and conditions, which can be viewed online.

https://apropos.erudit.org/en/users/policy-on-use/ 
Paideusis, Volume 17 (2008), No. 2, pp. 51-63

\title{
John Dewey: Closet Conservative?
}

\author{
DAVID I. WADDINGTON \\ Concordia University, Canada
}

\begin{abstract}
Several well-known scholars, including Clarence Karier, Walter Feinberg, and Eamonn Callan, have offered arguments suggesting that John Dewey was more politically conservative than is generally thought. Karier and Feinberg base their respective cases on Dewey's involvement with the Polish community during World War I, while Callan relies heavily on some remarks offered in one of Dewey's later works, Ethics. In the following account, it is suggested that neither of these analyses withstands careful scrutiny. In the case of the Polish affair, Karier and Feinberg are not able to marshal sufficient evidence to condemn Dewey convincingly, and there is a significant quantity of counterevidence which indicates that Dewey's intentions were benign. Callan's case, though seemingly convincing, is undermined by the joint authorship of the Ethics and by information contained in Dewey's correspondence. In conclusion, it is argued that the more popular understanding of Dewey as a left-liberal reformer is, in fact, correct.
\end{abstract}

\section{Introduction}

Recently, Human Events, a weekly conservative magazine, asked a panel of conservative scholars to vote on the "most harmful books of the $19^{\text {th }}$ and $20^{\text {th }}$ centuries." John Dewey's Democracy and Education was ranked at position \#5 with 36 votes, just behind The Kinsey Report and ahead of Das Kapital. The text which accompanied the ranking suggested, ominously, that Dewey's educational ideas had "helped nurture the Clinton generation." ${ }^{1}$ Clearly, the conservative scholars on the panel viewed Dewey as a kind of arch-villain of $20^{\text {th }}$ century liberalism.

Given Dewey's top billing on this list of enemies of the right, and given his general reputation as a leftist intellectual, one might be surprised to learn that he has, on occasion, been attacked by leftleaning critics. Two scholars, Clarence Karier and Walter Feinberg, suggested that Dewey was a "servant of power" who manipulated American workers on behalf of wealthy industrialists, ${ }^{2}$ while Eamonn Callan, a Canadian philosopher of education, held that Dewey's philosophy of education is more plausibly viewed as "politically conservative." 3 While each of these scholars argues that Dewey was, at heart, a conservative, they offer different justifications for their respective positions. Karier and Feinberg ground their critiques in an attack on Dewey's involvement with Polish immigrants during World War I, while Callan looks to Dewey's writings in the 1920s and 1930s to support his position.

\footnotetext{
${ }^{1}$ Human Events Magazine, “Ten Most Harmful Books of the $19^{\text {th }}$ and $20^{\text {th }}$ Centuries," Human Events, May 31, 2005. http://www.humaneventsonline.com/article.php?id=7591 (accessed March 6, 2008).

${ }^{2}$ Clarence Karier, "Liberalism and the Quest for Orderly Change", History of Education Quarterly 12, no. 1 (1972): 77.

${ }^{3}$ Eamonn Callan, "The Two Faces of Progressive Education," in Canadian Education, ed. E. Brian Titley (Calgary, Detselig Enterprises Inc., 1990), 84.

(C) Copyright 2008. The author, David I. Waddington, assigns to Paideusis the right of first publication and educational and nonprofit institutions a non-exclusive license to use this document for personal use and in courses of instruction provided that the article is used in full and this copyright statement is reproduced. Any other usage is probibited without the express permission of the author.
} 
Although the question of Dewey's alleged conservatism is interesting from a purely historical standpoint, it also has implications for progressivism writ large. In The Trouble with Ed Schools, David Labaree suggests that many faculty members in schools of education have an enduring faith in progressivism, and that this faith is linked to a commitment to Dewey's social and educational thought. ${ }^{4}$ Dewey's vision of education for social justice, says Labaree, can "really get an education professor's blood pumping." The arguments of Karier, Feinberg, and Callan, however, suggest that education professors may be misguided in their faith. Were these arguments to be accepted, they would alter our perception of Dewey's educational vision significantly, and might have a significant impact on the reputation of the most important apostle of educational progressivism.

This analysis is, therefore, dedicated to an examination of the various arguments for Dewey's conservatism. Since Karier's and Feinberg's respective cases are fairly similar, their arguments will be dealt with together in the first section of the paper. Callan's argument, which is significantly different, will merit its own section. As will become clear, although some of these authors offer worthwhile arguments, none of them are able to prove their case satisfactorily. There is little convincing evidence to indicate that Dewey was a "closet conservative."

\title{
Karier and Feinberg: An Attack on Dewey's Polish Project
}

In two separate articles written in the early 1970s, ${ }^{5}$ Clarence Karier and Walter Feinberg suggested that Dewey was a quiet but effective proponent of the existing power structure. The concluding remark of Karier's article gives one a sense of his disdain for Dewey:

\begin{abstract}
Whether it was Dewey calling for a more effective manipulation of the Polish immigrant during World War I or it was President Johnson manipulating public opinion so as to escalate the Vietnam War, liberals in crisis usually directly or indirectly supported the existing power structure. They were, in fact, Servants of Power. If, indeed, the unfortunate time shall come when the left confronts the right in open confrontation, little doubt should remain where many liberals will stand. ${ }^{6}$
\end{abstract}

Feinberg's paper is more nuanced and less fiery than Karier's, but it reaches a similar conclusion, namely that Dewey was an advocate for capitalist interests. Both Feinberg and Karier base much of their case against Dewey on a research project that Dewey participated in toward the end of World War I, which culminated in a report, "Confidential Report of Conditions among the Poles in the United States." In order to understand Karier and Feinberg's criticism of Dewey, it will be necessary to offer a cursory exposition of the substance of this report.

To those who are familiar with Dewey's work, the mere fact that he wrote a report on the Poles at all may appear rather strange. Dewey was a highly successful public intellectual at this time, but this particular activity was significantly outside his usual purview. As it happened, Dewey's investigation of the Polish community stemmed from a suggestion by his wealthy and eccentric ${ }^{7}$ friend Albert Barnes, who had been inspired to begin the project through his participation in one of Dewey's seminars at

\footnotetext{
${ }^{4}$ David Labaree, The Trouble with Ed Schools (New Haven: Yale University Press, 2004), 130.

5 Although Karier and Feinberg's respective articles have been extant for some time, the arguments offered by them pose a significant challenge to our vision of Dewey, and are worthy of careful examination.

${ }^{6}$ Karier, "Liberalism and the Quest for Orderly Change," 77.

${ }^{7}$ Barnes would frequently write angry letters that would be signed by a fictitious secretary ("Peter Kelly") or his $\operatorname{dog}$ ("Fidele-de-Port-Manech"). As far as Barnes' eccentricities go, this anecdote highlights the tip of a large iceberg. See Mary Ann Meyers, Albert Barnes and the Science of Philanthropy: Art, Education, and African-American Culture (New Brunswick, N.J.: Transaction, 2004), 220.
} 
Columbia University. ${ }^{8}$ Barnes was aware of the existence of a large, unintegrated Polish community in his native Philadelphia, and suggested that Dewey might be interested in investigating this group. ${ }^{9}$ In a letter to Dewey, Barnes noted that he wanted to "put to the pragmatic test some of the most vital principles" in Democracy and Education." 10 As I will explain later, Barnes was probably alluding here to Dewey's communitarian concerns about the problem of isolated groups in a democratic society. In a subsequent letter, Barnes gave a more specific indication of his concerns, commenting to Dewey, "I wish you would think over the general tendency of the Catholic Church to hold in a condition of intellectual and physical serfdom the large part of the population."11 Thus, the impetus for Barnes' concern appeared to be the isolation of the Poles from the rest of American society.

At the outset, the investigation was fairly diffuse in its scope-in May of 1918, with funding from Barnes, researchers were dispatched to investigate a wide variety of aspects of Polish-American life (e.g. schooling, neighborhood activities, the lives of women). ${ }^{12}$ However, perhaps because of Barnes' keen interest in politics, the report ended up focusing squarely on the political situation among the Poles in the United States. ${ }^{13}$ Barnes was extremely enthusiastic about the project, and would frequently visit the researchers to check in on their progress. ${ }^{14}$ During the first stages of the project, Dewey was not quite as "hands-on" as Barnes since he was on a lecture tour in California. ${ }^{15}$ Yet despite Dewey's absence and some initial growing pains (one research assistant whom the irascible Barnes deemed a "staller" left the project), the project acquired data swiftly. ${ }^{16}$ In July, Dewey made a presentation to the secret intelligence commission known only as "the Inquiry," which was gathering data to prepare for America's role at a possible peace conference. When this effort failed to bear fruit, Dewey and Barnes tried to interest Colonel Edward House, one of President Wilson's top advisors and a key player in the Inquiry, in some of the work that they had been doing, but this effort was not particularly successful. ${ }^{17}$ It was only after these failures that Dewey eventually managed to gain the attention of the Military Intelligence Division (MID), where one of his colleagues at Columbia was a top aide. ${ }^{18}$ The 80 page "Report of Conditions among the Poles" was submitted to the MID early in the fall of $1918 .{ }^{19}$

The core message of the report is a condemnation of the conservative faction in PolishAmerican affairs. Dewey suggested that this conservative faction was closely aligned with the Paris committee, a group of Poles who had managed to secure recognition from France and England as a kind of government-in-exile. Dewey took pains to point out that the Paris committee was headed by Roman Dmowski, the leader of the National Democrats, a right-wing party which had strong Tzarist and anti-Semitic tendencies. ${ }^{20}$ Dmowski and his American allies were opposed by the KON (Committee of National Defense), a group with distinctly more leftist sympathies. Dewey summed up the Polish-American political situation as follows:

\footnotetext{
${ }^{8}$ Robert B. Westbrook, John Dewey and American Democracy (Ithaca: Cornell University Press, 1991), 221.

9 John Dewey, The Middle Works, vol. 7, ed. Jo Ann Boydston (Carbondale: Southern Illinois University Press, 1979), 398.

${ }_{10}$ Albert C. Barnes to John Dewey, 1918.04.20, Dewey Correspondence; Dewey, Middle Works, vol. 11, 399.

11 Albert C. Barnes to John Dewey, 1918.05.24, Dewey Correspondence.

12 Dewey, Middle Works, vol. 11, 260.

${ }_{13}^{13}$ Meyers, Albert Barnes and the Science of Philanthropy, 49; Dewey, Middle Works, vol. 11, 259-260

14 Somehow, during this period, Barnes managed to get himself arrested for "fighting and resisting an officer," and one biographer has suggested that he and some of the research assistants spent some time together in the saloons of Philadelphia! See Meyers, Albert Barnes and the Science of Philanthropy, 49.

${ }_{15}$ Boydston, Middle Works, vol. 11, 407.

${ }^{16}$ Albert C. Barnes to John Dewey, 1918.06.28, Dewey Correspondence.

${ }_{17}$ Boydston, Middle Works, vol. 11, 403-405.

${ }^{18}$ Boydston, Middle Works, vol. 11, 406.

${ }^{19}$ Ibid., 407.

${ }^{20}$ Dewey, Middle Works, vol. 11, 278-279.
} 
On the one hand the remnant of the KON...is associated with the political policies of the radical group...on the other hand is the priestly and conservative faction which, since 1914, has been directly connected with the National Democratic party....and engaged in endeavoring to mould the mass of the Poles in this country in support of that faction. ${ }^{21}$

This molding, according to Dewey, took the form of the Detroit convention, a national gathering organized by the American allies of the conservative Polish faction. Although the stated purpose of the convention was to solicit a consensus among Polish-Americans about the efforts necessary to secure a free Poland, Dewey contended that the convention was actually a manipulative piece of political theatre which was intended to legitimate the agenda of the conservative faction. Dewey compared the delegate selection process to the machine politics of Tammany Hall and pointed out that there was virtually no space for democratic deliberation at the convention. ${ }^{22}$

From the account so far, Dewey and Barnes seem to be engaged in a well intentioned, albeit perhaps naïve and paternalistic, intervention in the affairs of an ethnic minority group in the US; no evidence of advocacy for capitalist interests has entered our narrative. However, as Karier and Feinberg point out, there are some more worrisome aspects of the report. A significant strand of Dewey's argument against the conservative faction rests on that faction's opposition to the Americanization of the Poles. Dewey noted, with some disapproval, that conservative elements of the Polish community were opposed to American public education. ${ }^{23}$ In addition, he pointed out that while the KON supported recruitment for the U.S. army, the conservative factions were trying to recruit for the National Polish Army. He eventually concluded his argument against this "de-Americanizing tendency" with the following comment:

With the sharp commercial competition that will necessarily take place after the war, any tendencies which on the one hand de-Americanize and on the other hand strengthen the allegiance of those of foreign birth to the United States deserve careful attention. ${ }^{24}$

Not surprisingly, Karier and Feinberg were quick to seize upon this naked appeal to the pocketbooks of the upper class. Feinberg suggests that Dewey wanted to keep "the wheels of industry running, during the war and afterwards as well." 25

In addition to the remark mentioned immediately above, Feinberg also draws on an interview that he conducted with one of the Dewey's former students (and a research assistant on the Polish project itself), Brand Blanshard. In the interview, Blanshard suggested that Dewey viewed the Poles as a "cyst on American society." 26 However, Blanshard later retracted this claim in a 1973 letter. He remarked, "I do not know whether Dewey used the word "cyst" in referring to the Polish community. It was used by me to describe the problem that I think we all conceived ourselves as facing, most of all perhaps Dr. Barnes." 27

Feinberg's and Karier's articles prompted a response from a historian, Charles Zerby. Zerby maintains that Dewey's primary concern in the Polish project was to investigate whether the Poles were

\footnotetext{
21 Ibid., 291.

22 Ibid., 243.

23 Ibid., 290.

24 Ibid., 324.

${ }_{25}$ Walter Feinberg, "Progressive Education and Social Planning," Teachers' College Record 73, no. 4 (1972): 494.

${ }^{26}$ Ibid., 491.

${ }^{27}$ Boydston, Middle Works, vol. 11, 399.
} 
being oppressed domestically and represented internationally by conservative, anti-Semitic political groups. ${ }^{28}$ Zerby quotes Brand Blanshard, who remarked:

Dewey found the Polish community itself rather sharply divided, and I think his chief concern was that the reactionary segments of Polish opinion should not have the exclusive ear of Washington. He was looking forward to the state of Poland after the war, and was anxious that the State Department should not throw its weight behind a conservative economy in Poland. ${ }^{29}$

The balance of evidence presented in the report appears to lean towards Zerby's analysis of the situation rather than Karier's or Feinberg's. As I have suggested above, the vast majority of the report is dedicated to the task of excoriating the manipulative role of the conservative faction in Polish affairs, and this theme is so dominant that it casts doubt on Karier and Feinberg's efforts to portray Dewey as a "servant of power." In an article written shortly after the publication of the report, Barnes noted that he (and possibly Dewey as well) had been investigated by the Department of Justice for alleged proGerman sympathies. ${ }^{30}$ Thus, although the report may have had contained some capitalist/authoritarian pronouncements, some elements of the American government clearly had reservations about the political leanings of the report.

Of course, one could raise the objection that it is possible to criticize Polish conservatives and simultaneously be a servant to American capitalist interests. However, one reason that this state of affairs is unlikely lies in the personality of Barnes himself. Barnes' attitude toward his fellow capitalists is best described by the phrase, "extreme loathing." He came from a working-class background, and when he became wealthy, the elite of Philadelphia viewed him as an uncultured arriviste. ${ }^{31}$ Having endured this early disdain, he later took great delight in denying the wealthy access to his famous art collectionwhen car magnate Walter Chrysler wrote to Barnes to request permission to view Barnes' art collection, fictitious secretary "Peter Kelly" responded that Barnes was too busy breaking "the world's record for goldfish swallowing" to bother to answer Chrysler's letter. ${ }^{32}$ If Barnes had felt that the one of the purposes of his and Dewey's project was to defend the interests of American captains of industry, it is unlikely that he would have been such an enthusiastic participant.

Still, the overall political tenor of the report and Barnes' dislike of the establishment cannot obscure the fact that the report contains some significant pronouncements about both assimilation and capitalism. However, there may be another way in which these facts can be accounted for; perhaps Dewey was using every tactic at his disposal to persuade the intelligence bureau that his views were correct. As Bruno Latour, a sociologist of science, has pointed out, one promising tactic to employ when constructing social facts is to enlist others' interest by saying, "I want what you want." 33 Dewey had a colleague inside the agency, and he may have known that MID's concern about the problem of leftist labor disruptions had reached a feverish state. ${ }^{34}$ Through an appeal to capitalist interests, Dewey may have been trying to convince the MID (which, as noted above, was not the agency he most wanted to be dealing with in the first place) that despite appearances to the contrary, his project was aligned with their primary concerns. Perhaps this is an overly cynical interpretation of Dewey's motives, but by

${ }^{28}$ Charles Zerby, "John Dewey and the Polish Question: A response to the revisionist historians," History of Education Quarterly 15, no. 1 (1975): 20-22.

${ }^{29}$ Boydston, Middle Works, vol. 11, 400.

${ }^{30}$ Albert Barnes, "Democracy, Watch your Step!" Dial, December 28, 1918, 597.

${ }^{31}$ Howard Greenfield, The Devil and Dr. Barnes (New York: Viking, 1987), 5-6; 28-29.

32 Meyers, Albert Barnes, 220.

${ }_{33}$ Bruno Latour, Science in Action (Cambridge, MA: Harvard University Press, 1987), 108.

${ }^{34}$ Laurie and Cole, The Role of Federal Military Forces in Domestic Disorders, 1877-1945 (Washington, D.C.: Center of Military History, 1997), 328; Joan M. Jensen, Army Surveillance in America, 1775-1980 (New Haven: Yale University Press, 1991), 137-177. 
immersing himself in the Polish project and becoming involved with the MID, Dewey had thrust himself into the world of realpolitik.

An additional exculpatory explanation of Dewey's approach to the Polish situation can be found in Democracy and Education. This connection is not terribly surprising, since Barnes had intended the Polish project to be closely linked to the ideals espoused in the book. In Chapter 2 of Democracy and Education, Dewey exhibited some concern about the isolation of immigrant groups from the rest of American culture. Noting the diversity of America's new immigrants, he commented:

It is this situation which has, perhaps more than any other one cause, forced the demand for an educational institution which shall provide something like a homogeneous and balanced environment for the young. Only in this way can the centrifugal forces set up by juxtaposition of different groups... be counteracted. ${ }^{35}$

This remark is characteristic of Dewey's sentiments regarding immigrants in Democracy and Education. In a later chapter of the book, Dewey set up a standard for judging the worth of particular forms of social life. One of the two criteria that make up the standard is the "amount of interaction and cooperative intercourse with other groups." 36 Isolation was a significant obstacle to the realization of Dewey's vision of the good society because, for Dewey, democracy was not merely a political system, but was rather "a mode of associated living, of conjoint communicated experience." 37 This communitarian conception of society is not inimical to all forms of difference, but it is certainly set against groups which refuse to interact and cooperate with other segments of society. Dewey felt that the problem of isolation helped maintain cultures and classes in a state of marginalization. A true democratic community would require extensive dialogue and cooperation, which was not compatible with isolation.

Obviously, Dewey's concerns about group isolation would not square particularly well with today's prevailing theories about multiculturalism and education; his ideas have an air of assimilationism about them. However, this does not mean that Dewey can be branded as a conservative, or as a nativist or xenophobe. In fact, compared to some of his contemporaries, Dewey's vision of American society seems remarkably inclusive. At the time that Dewey submitted the report to the MID, nativist and xenophobic forces in the United States were especially strong. In March of 1918, a few months before the Polish report was issued, popular journalist Samuel Hopkins Adams wrote, "Reckon each [immigrant] as a pound of dynamite-surely a modest comparison." 38 Meanwhile, the Justice Department, in cooperation with American businessmen, had set up a volunteer secret police forcethe American Protective League (APL). ${ }^{39}$ This force, 250,000 men strong, was deputized to report the disloyal actions of fellow citizens. The APL paid particular attention to socialists, a faction to which Dewey was quite sympathetic in the report.

Ultimately, neither of the two explanations offered above-Dewey's engagement in realpolitik and his commitment to communitarianism-can extricate him entirely from blame. In the final analysis, the report may merit some opprobrium for its paternalism and its efforts to pander to the dominant interests at the MID. However, the fact remains that the report appears to be well intentioned: Dewey wanted the Poles to become an integrated part of American life, and he was genuinely outraged about the predominance of reactionary elements among their leadership. Although the production of this report was not a highlight of Dewey's career as a public intellectual, it is not nearly as damning as the narratives of Karier and Feinberg would suggest. Far from showing up Dewey as a "servant of power,"

\footnotetext{
35 Dewey, Democracy and Education (New York: MacMillan, 1916), 21.

36 Ibid., 83.

${ }^{37}$ Ibid., 87.

38 Quoted in John Higham, Strangers in the Land: Patterns of American Nativism 1860-1925 (New Brunswick, NJ: Rutgers University Press, 1955), 214.

${ }^{39}$ Higham, Strangers in the Land, 211.
} 
the report conveys an impression of him as an enthusiastic (but perhaps bumbling) proponent of the left-liberal forces in Polish affairs.

\section{Callan: Deweyan Education for Good Corporate Citizens}

Whereas Karier and Feinberg rely on a relatively obscure aspect of Dewey's work to ground their analysis of him, Eamonn Callan's criticism strikes closer to the heart of Dewey's overall project. Callan's analysis relies on a range of Dewey's work from the 1920s and 1930s, a period of Dewey's life in which he was a prominent public intellectual. At the opening of his article, "The Two Faces of Progressive Education" (1988), Callan states his view succinctly:

If we view the key ideas of [Dewey's] philosophy in a particular way, emphasize some passages in his writings, and overlook others, his social theory seems to support a form of radical socialism. Given an alternative interpretation of Dewey, his social and educational philosophy appears in a politically conservative light. ${ }^{40}$

Callan is keen to advance the latter interpretation, and he thinks he has marshaled sufficient evidence to make a convincing case.

Callan's analysis begins by taking aim at Dewey's program for education through occupations. This program, the core of which is outlined in School and Society, focused on instilling habits of selfdiscipline and cooperation, and on developing students' familiarity with science and technology. ${ }^{41}$ At the Dewey School, students recapitulated the development of science and technology using techniques that we would recognize as being similar to what we today refer to as "discovery learning." 42 Some scholars, and, indeed, some of the original teachers at the Dewey school, have suggested that this brand of education was intended to promote a left-liberal vision of social change. ${ }^{43}$ As Callan acknowledges, there is significant textual support for this view in the Deweyan corpus. For example, in "My Pedagogic Creed," one of his earliest pieces on education, Dewey commented, "I believe that education is the fundamental method of social progress and reform." 44 In School and Society, he lamented the fact that workers were "appendages to the machines they operate," and his concern about this problem appears to motivate the development of his new educational program, which was intended to produce thoughtful, knowledgeable workers who were capable of free and effective action in the world. ${ }^{45}$

Callan, however, points out that Deweyan education could be easily used to promote conservative ends. For example, he points out that Dewey's emphasis on the role of science and technology in education could be used as a tool for the furthering the ends of large corporations. He comments, "scientific intelligence is valued as an attribute which ensures successful adaptation in a society where rapid technological change is the only stable fact of life." ${ }^{46}$ Callan's point here is valid; many of the skills which Deweyan education through occupations is supposed to develop-habits of discipline,

\footnotetext{
${ }^{40}$ Callan, "The Two Faces of Progressive Education," 84.

41 John Dewey, The School and Society and the Child and the Curriculum (Chicago: University of Chicago Press, 1990), 6-29.

42 Ibid., 38-39.

43 See, for example, Katherine Camp Mayhew and Anna Edwards, The Dewey School (Chicago: D. Appleton Century Co., 1936), 314; David K. Cohen, “Dewey's Problem,” The Elementary School Journal 98, no. 5 (1998).

${ }^{4}$ John Dewey, The Early Works, vol. 5, ed. Jo Ann Boydston (Carbondale: Southern Illinois University Press, 1973), 93.

${ }^{45}$ Dewey, School and Society, 24.

${ }^{46}$ Callan, "The Two Faces of Progressive Education," 87.
} 
cooperation, and scientific/technological insight—are on the list of qualities that corporations look for in prospective employees. ${ }^{47}$

Clearly, however, the fact that Deweyan education is compatible, at least on the surface, with corporate capitalism is not sufficient to establish the existence of this "other face" of progressive education-textual evidence is required as well. Callan realizes this, and he thinks that he has found some worthwhile evidence in Ethics (1932), a textbook that Dewey co-wrote with James Tufts, a philosophy professor from the University of Chicago. Callan believes that Ethics reveals Dewey's allegiance to status quo corporate capitalism, and he paraphrases the book at length:

[Dewey and Tufts] maintained that tendencies within modern capitalism were already at work to right the wrongs it had spawned. First, [they] approvingly cited Henry Ford's claim that the new technologies of mass production worked to everyone's benefit, workers and capitalists alike. They noted that the investment of labour in industry might blur class divisions in the future and lead to workers having greater control in economic matters...Although they regarded extreme inequalities of wealth as repugnant to democracy...they were quick to add that strict equality in the distribution of goods "fails to give sufficient weight to the differences among men, not only in ability but in willingness to do their share of work. ${ }^{48}$

Callan summarizes his findings: "In short, Dewey's and Tuft's agenda for the democratization of industry contains little to disturb all but the most fervent laissez-faire capitalists." 49

Despite this seemingly compelling evidence, one should not be too quick to accept Callan's conclusion. If, in 1932, Dewey were prepared to endorse the economic status quo, this would be at odds with the kinds of sentiments he had expressed earlier in works like Impressions of Soviet Russia and the Revolutionary World (1929) and Individualism: Old and New (1930)..$^{50}$ In the former book, Dewey praised the innovations made by the Russian schools and lauded the revolutionary spirit and energy displayed by the citizens of the new regime. ${ }^{51}$ In the latter work, Dewey condemned the profit motive and the ideal of the rugged individual, all the while calling for greater cooperation among citizens. ${ }^{52}$ Clearly, none of these sentiments seem to fit the portrait of Dewey that Callan presents. Thus, this apparent contradiction in the Deweyan corpus has two possible resolutions: either Dewey repudiated his earlier, more radical position, or he simply did not mean what he said in the Ethics. Surprisingly, although the latter possibility appears to be unlikely, there is compelling evidence which demonstrates its truth.

The primary reason why Dewey should not be held responsible for some of the sentiments expressed in the Ethics is simple: he didn't write them. The Ethics is divided into three parts: "The Beginnings and Growth of Morality," "Theory of Moral Life," and "The World of Action." Dewey wrote the second part, as well as the first two chapters of Part III, which is mostly concerned with economic life. Dewey's co-author, Tufts, wrote all of Part I and Part III, except the first two chapters. ${ }^{53}$ Notably, all of the text with which Callan takes issue was actually written by Tufts.

\footnotetext{
${ }^{47}$ Notably, George Babbitt, the protagonist of Sinclair Lewis's eponymous novel, possesses a number of rather Deweyan virtues. He is a disciplined man, an enthusiastic cooperator, and has a significant interest in science and technology. At the same time, however, he is also a strong opponent of social reform. See Sinclair Lewis, Babbitt (New York: Harcourt, Brace, and Co., 1922).

${ }^{48}$ Callan, "The Two Faces of Progressive Education," 89

${ }^{49}$ Ibid., 89.

${ }^{50}$ Interestingly, it would also be at odds with Dewey's FBI file. The FBI was suspicious of Dewey's links to leftist organizations, and developed an extensive (more than 200 page) dossier on Dewey. See John A. Beineke, "The Investigation of John Dewey by the FBI," Educational Theory 37, no. 1 (1987).

51 John Dewey, Impressions of Soviet Russia and the Revolutionary World (New York: Teachers College, 1964), 49, 82.

52 John Dewey, Individualism: Old and New (New York: Prometheus, 1999), 26-49.

53 John Dewey, The Later Works, vol. 7, ed. Jo Ann Boydston (Carbondale: Southern Illinois University Press, 1981), 7 .
} 
Callan might maintain, however, that this evidence is not sufficient to exculpate Dewey from the conservative tendencies expressed in the book. Tufts may well have written the offending chapters, but Dewey had read Tufts' material and had given it the stamp of approval in the form of co-authorship. ${ }^{54}$ However, new information made available by the recent publication of Dewey's correspondence shows otherwise. Dewey's letters to Tufts about the book indicate that Dewey had significant reservations about the overall slant of some of Tufts' work. Consider the following remark by Dewey to Tufts:

I suppose I've got more pessimistic about the future as I've got more radical in the atmosphere of NY, so I'll content myself with [r] epeating my admiration and my incidental hope that some of the points made might be made a little sharper as to alternative possibilities. 55

The running commentary on Tufts' draft that accompanies the letter shows that in his quiet, polite way, Dewey was attempting to voice some doubts about Tufts' analysis of the economic situation-when he is talking about "alternative possibilities," he appears to be pointing towards more radical, socialist possibilities. For example, in one comment, Dewey dwelled on the importance of worker participation:

...there is one point which it seems to me might be more emphasized; and that is, the intellectual effect of not merely motonony [sic], extreme division of labor, but of having no part in forming the plans, no intellectual and personal (emotional participation) in work save as regards wage gained...Also effect on self-respect-one of the striking things in Russia is the way workment [sic] speak of our factory, and the greater sense of personal status. ${ }^{56}$

At a later juncture in the same letter, Dewey reiterated a point about the profit motive which he had originally made some years earlier in the first chapter Individualism: Old and New:

I should like to see a little more about the reflex effects [of the profit motive] on the personality of laborers, capitalists and business men. Perhaps it is from living in NY but I'm more and more impressed by a certain crule [sic] and rapacious irresponsibility that develops in financial leaders_-along with a rationalizing insincerity. ${ }^{57}$

Finally, in a different letter to Tufts, written about a year later, Dewey indicated that he has located the central "problem" of capitalism:

The esential [sic] problem about capit[a]lism seems to me whether society can go on paying tribute, through investments wh[ich] are manipulated, to "property", especially credit, land, and utilities, and yet do what the upholders of capitalism say it will do in bringing a respectable standard of living to all, including security. ${ }^{58}$

\footnotetext{
54 A later letter between Joseph Ratner and Arthur Bentley sheds some light on Dewey's thinking about coauthorship. Bentley was collaborating on a book with Dewey in the same way that Dewey and Tufts had collaborated, i.e. Dewey and Bentley were drafting the chapters separately. Bentley asked whether the chapters he wrote should be attributed to him in the table of contents. Ratner was adamant that that was the wrong way to proceed. He remarked, "I would not have the authorship notations in the Table of Contents. It is not necessary and is quite unattractive looking. In Dewey and Tufts Ethics, some chapters of Part III are written by JD and some by Tufts. So that JD would accept such arrangement, since that is what he is used to. Notation in Preface is absolutely adequate." See Arthur F. Bentley to Joseph Ratner, 1947.09.08, Dewey Correspondence; Joseph Ratner to Arthur F. Bentley, 1947.09.30, Dewey Correspondence.

${ }^{55}$ John Dewey to James H. Tufts, 1930.08.09, Dewey Correspondence.

56 Ibid.

${ }^{57}$ Ibid.

${ }^{58}$ John Dewey to James H. Tufts, 1931.07.11, Dewey Correspondence.
} 
These are only a few of the many examples of Dewey's left-leaning misgivings and suggestions concerning Tufts' Part III of the Ethics. Interestingly, in contrast to this outpouring of commentary on Part III, Dewey offered virtually no comments on Part I of the Ethics, which had also been written by Tufts and which covered the historical development of ethical thought. As far as Part I was concerned, Dewey simply wrote, "I have gone over the sheets indicating changes in Part I and have found them interesting, highly so. I don't have any suggestions [a]bout them." 59

Although Tufts' passages in the Ethics account for much of Callan's best evidence, he has some additional quotes that he marshals against Dewey. For example, Callan considers the following remark, from "The Need of an Industrial Education in an Industrial Democracy," (1916) to be particularly worrisome:

The imagination must be so stored that in the inevitable monotonous stretches of work, it may have worthy material of art and literature and science upon which to feed, instead of being frittered away upon undisciplined dreamings and sensual fantasies. ${ }^{60}$

Like the comments that Karier and Feinberg draw to our attention, this remark appears to be both paternalistic and patronizing. Far from valorizing the contributions of the workers, this statement portrays the workers as an undisciplined group in need of greater self-control in order to resist the siren song of their baser instincts. Furthermore, the tenor of the remark brings to mind the stereotypical image of the conservative intellectual ${ }^{61}$ — an older man sitting in his armchair, puffing on a cigar, and pontificating about the deplorable "sensual fantasies" of the workers.

Yet, although this quote may tempt us toward this image, there are good reasons to restrain ourselves from temptation. First, this remark belies the tone of the essay from which it is taken. "The Need of an Industrial Education in an Industrial Democracy" is an essay in which Dewey railed against skill-based vocational education, calling instead for a thorough education in science and technology, which he maintained would be necessary if workers were ever to transform the current "industrial feudalism" into an industrial democracy. ${ }^{62}$ Dewey also noted that workers needed to be educated so as to be discontented with mechanical factory labor-he remarked, "Personal control of power, strong discontent with whatever subordinates mental capacity to merely external regulation must be made primary." ${ }_{33}$ In an essay written shortly thereafter, he again emphasized this point, indicating that teachers had a choice between being "servants of democracy" and furthering the interests of wealthy industrialists who wanted compliant workers. ${ }^{64}$ Second, despite its patronizing tone, the argument contained in the quote is not without merit. Dewey realized that even if industrial democracy were to become a reality, the exigencies of mass production would still imply inevitable long, boring stretches of work. Is it really so unreasonable to suggest that a robust system of education could help generate effective ways of coping with this slack time?

${ }^{59}$ John Dewey to James H. Tufts, 1932.02.11, Dewey Correspondence.

${ }^{60}$ Dewey, Middle Works, vol. 10, 140.

${ }^{61}$ There is an implicit question in this paper about what, exactly, a conservative is. A broad spectrum of thinkers call themselves conservatives, and there are significant differences between the ideas of, say, Robert Stanfield, Milton Friedman, and Pat Robertson. Karier, Feinberg, and Callan appear to be using "conservative" to signify a commitment to upholding status-quo capitalism. As I have pointed out, this particular definition does not fit Dewey very well.

However, conservatism wears many guises, and Dewey would not have rejected ideas out of hand simply because these ideas were traditionally associated with conservatism. One could imagine, for example, Dewey being sympathetic towards a wariness of excessive bureaucracy or a desire to conserve rural communities.

${ }^{62}$ Dewey, Middle Works, vol. 10, 142.

63 Ibid., 140.

${ }^{64}$ Ibid., 210. 
In sum, a wide array of evidence suggests that Callan may be mistaken when he says that Deweyan education aims to create what Callan terms "the adaptable employee." Of course, as has been noted, it is true that Deweyan education through occupations does aim to prepare workers to be insightful, creative and cooperative, which are all traits which might be valued in some contemporary corporate settings. However, this compatibility with corporate goals does not imply that Dewey was actually interested in furthering corporate goals.

Dewey was, in fact, interested in corporations, but in a sense of the word that is quite different from the contemporary sense. As Dewey detailed at some length in Individualism: Old and New, a work which is contemporaneous with the works upon which Callan grounds his criticism, Dewey's new individual was intended to be a corporate individual in the sense that she was to supposed to possess the skills and disposition necessary to form cooperative communities with others. ${ }^{65}$ Dewey was not specific about how this "new corporatism" would replace and/or relate to existing economic structures, but it is quite clear that Dewey wanted the new corporatism to be one in which worker's voices were more powerful. Power, intelligently exercised, requires a high degree of competency, and this outcome was precisely what Dewey's lifelong emphasis on scientific and technological education was meant to bring about. If industrial democracy were to be made workable, everyone would have to be a thoughtful, cooperative worker.

\section{Conclusion}

In the preceding analysis, I have suggested that the analyses of Karier, Feinberg, and Callan are flawed. Dewey simply cannot be regarded as a conservative in the conventional sense of the word, closeted or otherwise. The evidence for Dewey's conservatism is paltry in quantity and suspect in quality. Meanwhile, there is an enormous quantity of evidence, far more than could ever be detailed here, that demonstrates Dewey's sincere commitment to the leftist, progressive cause. Yet, despite this overwhelming evidence in support of Dewey, there is still something seductive about the analyses of Karier, Feinberg, and Callan. This raises a fitting question ${ }^{66}$ with which to conclude: why is there this temptation to embrace this counterinterpretation and to brand Dewey as a conservative?

If one rejects the various interpretations and arguments that have been presented above, one might be tempted to say that it is the bare facts of the case that drive one towards the conclusion that

${ }^{65}$ John Dewey, Individualism: Old and New (New York: Prometheus, 1999), 37-49.

${ }_{66}$ Notably, there is also another important question which could be posed here: if Dewey did, in fact, espouse some pro-corporate positions, particularly of the type that Callan describes, would it discredit him? Certainly, the title of this paper implies that the answer is "Yes." This may, in fact, be problematic. Sometimes, in the field of education, we tacitly endorse a kind of left/right Manicheanism; we are tempted to condemn anything conservative or pro-corporate out of hand. This tendency is particularly visible in Karier's work-when Karier wrote, "If, indeed, the unfortunate time shall come when the left confronts the right in open confrontation, little doubt should remain where many liberals will stand," one gets the sense that allegedly pro-corporate liberals like Dewey were going to be first against the wall when the revolution came.

In addition to avoiding left/right Manicheanism, it may also be necessary to pay due heed to pro-corporate arguments. As Dewey pointed out in Individualism: Old and New, the corporation is a key institution of modern society that provides significant benefits and is not going to disappear anytime soon. If one accepts this proposition, one could easily offer an argument that an education that produces good employees for corporations will benefit all of us to some degree.

Yet although this argument is not without its merits, it would be a distortion of the historical record to suggest that Dewey held this position. Dewey recognized the contributions of the corporation, but he wished to change the shape of this institution-he wanted to reform it to make it more democratic. Thus, in his recognition of the power of the corporation, Dewey is "pro-corporate," but he is also "anti-corporate" in terms of his reservations about the profit motive. 
Dewey had conservative tendencies. However, I would like to raise an alternative possibility. I suspect that some of us, in our mind's eye, have a particular vision of the social reformist educator. Whatever idea we have, it is probably quite different from the reality of Dewey. Dewey did not usually offer the kinds of bold, inspiring exhortations that our ideal radical educators might pour forth. When George Counts delivered his famous talk, "Dare Progressive Education Be Progressive?" at the 1932 meeting of the Progressive Education Association, the audience members were so electrified by it that they were stunned into silence. ${ }^{67}$ The day after Counts' speech, the other discussions that had been planned as part of the meeting were cancelled. ${ }^{68}$ Dewey, by contrast, was far more likely to put audience members to sleep than to shock them into silence. ${ }^{69}$

At first glance, Dewey does not seem to have a radical vision; there is no language about seizing the means of production, and he often fails to give us a clear notion of what a reformed society dominated by the "new individualism" would look like. Yet we should not dismiss Dewey because of his lack of fiery leftist rhetoric. The difficulty with envisioning the shape of massive social change before it happens is that social action gets forced into preset paths that may not be appropriate for the actual situation. A different, and perhaps better, approach to social change may be to refuse to specify the shape of social change in advance. If social change is to be truly democratic, it needs to be placed in the hands of the demos, in the hands of the workers and citizens who will actually make the change. Using education through the occupations, Dewey hoped to give people the disposition to want to solve social problems as well as the ability to tackle them effectively. He refused to state the solutions to these problems in advance, and this democratic silence, coupled with his humble, understated style, has led some commentators to endorse the erroneous belief that Dewey was a closet conservative.

\section{Acknowledgments}

The author would like to thank D.C. Phillips, Anne Newman, Eamonn Callan, Ray McDermott, William Knitter, Noah Feinstein, Nick Fiori, and Christa Compton for their support, their commentary, and their criticisms. The author would also like to acknowledge the contributions of the anonymous reviewers.

\section{References}

Beineke, John A. “The Investigation of John Dewey by the FBI," Educational Theory 37, no. 1 (1987): 43-52.

Callan, Eamonn. “The Two Faces of Progressive Education.” In Canadian Education, edited by E. Brian Titley, 83-94. Calgary, Detselig Enterprises Inc., 1990.

Cohen, David K. "Dewey's Problem,” The Elementary School Journal 98, no. 5 (1998): 427-476.

Cremin, Lawrence. The Transformation of the School. New York: Vintage, 1964.

Dewey, John. Democracy and Education. New York: MacMillan, 1916.

- Individualism: Old and New. New York: Prometheus, 1999.

. The Correspondence of John Dewey. Edited by Larry A. Hickman. Carbondale: The Center for Dewey Studies, 2005. http://library.nlx.com.

- The Early Works. Edited by Jo Ann Boydston. Carbondale: Southern Illinois University Press, 1973.

\footnotetext{
${ }^{67}$ Lawrence Cremin, The Transformation of the School (New York: Vintage, 1964), 260.

${ }^{68}$ Ibid, 260.

${ }^{69}$ George Dykhuizen, The Life and Mind of John Dewey (Carbondale: Southern Illinois University Press, 1973), 249250.
} 
- The Middle Works. Edited by Jo Ann Boydston. Carbondale: Southern Illinois University Press, 1979.

—. The Later Works. Edited by Jo Ann Boydston. Carbondale: Southern Illinois University Press, 1981.

- The School and Society and The Child and the Curriculum. Chicago: University of Chicago Press, 1990.

Dykhuizen, George. The Life and Mind of John Dewey. Carbondale: Southern Illinois University Press, 1973.

Feinberg, Walter. "Progressive Education and Social Planning," Teachers' College Record 73, no. 4 (1972): 485-505.

Greenfield, Howard. The Devil and Dr. Barnes. New York: Viking, 1987.

Higham, John. Strangers in the Land: Patterns of American Nativism 1860-1925. New Brunswick, NJ: Rutgers University Press, 1955.

Human Events Magazine. "Ten Most Harmful Books of the 19th and 20th Centuries." Human Events, May 31, 2005. http://www.humaneventsonline.com/article.php?id=7591 (accessed March 6, 2008).

Jensen, Joan M. Army Surveillance in America, 1775-1980. New Haven: Yale University Press, 1991.

Karier, Clarence. "Liberalism and the Quest for Orderly Change", History of Education Quarterly 12, no. 1 (1972): 57-80.

Labaree, David. The Trouble with Ed Schools. New Haven: Yale University Press, 2004.

Laurie, Clayton D. and Ronald Cole. The Role of Federal Military Forces in Domestic Disorders, 1877-1945. Washington, D.C.: Center of Military History, 1997.

Latour, Bruno. Science in Action. Cambridge, MA: Harvard University Press, 1987.

Lewis, Sinclair. Babbitt. New York: Harcourt, Brace, and Co., 1922.

Meyer, Mary Anne. Albert Barnes and the Science of Philanthropy: Art, Education, and African-American Culture. New Brunswick, N.J.: Transaction, 2004.

Westbrook, Robert B. John Dewey and American Democracy. Ithaca: Cornell University Press, 1991.

Zerby, Charles. "John Dewey and the Polish Question: A response to the revisionist historians," History of Education Quarterly 15, no. 1 (1975): 17-30.

\section{About the Author}

David I. Waddington is an Assistant Professor of Philosophy of Education at Concordia University in Montreal, Quebec. His current research interests include Dewey's early work, the history of progressive education, and new approaches to science and technology education. He can be reached at dwadding@education.concordia.ca 